JOURNAL DE PHYSIQUE IV

Colloque C7, supplément au Journal de Physique III, Vol. 1, décembre 1991

C $7-29$

\title{
MEDICAL APPLICATIONS OF PULSED LASERS
}

S. MORDON and J.M. BRUNETAUD

INSERM U 279, 1 rue du Professeur Calmette, F-59019 Lille, France, et, Laboratoire des Lasers, Faculté de Médecine, F-59045 Lille cedex, France

Medical applications of lasers are usually classified into four groups : electro-mechanical interaction (10ps to 10ns pulses), photoablative interaction (10 ns to $100 \mathrm{~ns}$ pulses, ultravioiet). thermal interaction ( $1 \mathrm{\mu s}$ to $1 \mathrm{~s}$ ) and photochemical interaction (1min to $10 \mathrm{~min}$ ). The first three groups are using pulsed lasers. In the electro-mechanical interaction, high-peak power laser pulses create high irradiances $\left(1010 \mathrm{~W} . \mathrm{cm}^{-2}\right.$ for $10 \mathrm{~ns}$ Q-switched pulses to $10^{12} \mathrm{~W} . \mathrm{cm}^{-2}$ for mode-locked 30ps pulses) which locally generate high electric fields resulting in dielectric breakdown and then formation of micro-plasma. The shock-wave associated is used for opening or disruption of ophthalmic structures. The photoablative interaction has recently been exploited to produce well defined, non-necrotic photoablative cuts. Excimer lasers, with short pulses (10ns) focused on tissue $\left(10^{8} \mathrm{~W} . \mathrm{cm}^{-2}\right)$ have been applied for ablation of the comea and for cardiovascular surgery. The thermal interaction relies on the conversion of electromagnetic energy into heat. Heating of tissues results in thermal injury, tissue removal, control of bleeding or localized fragmentation. The major problem with heating of tissue is to adjust the duration of laser exposure in function of the tissue thermal relaxation time. This quantity depends on wavelenght and tissue parameters. For this reason, numerous lasers are now applied in medicine such as Argon, Krypton, Nd YAG, CO2, Copper vappour, CW and pulsed dye, ... By using pulses lasting from $1 \mu \mathrm{s}$ to $400 \mu \mathrm{s}$, fragmentation of kidney-stone and vaporization of tissue are possible. With lasers operating in a repetitively pulsed or bust mode (ms pulses), selective photothermolysis and control of tissue temperature are achieved.

Reference : MORDON S., DE WITTE O. Lasers en Médecine. Techniques de l'Ingénieur, E 4930,6-1990 